plex and co-ordinate movements; nor is it improbable that, independently of these sensations, or of the muscular sense, it may react upon impressions transmitted to it, as suggested by Dr. Carpenter, who, not only in his last, but in the fourt $h$, edition, (1853,) of his "Human Physiology," distinctly announced it as probable that the cerebellum is subservient to the muscular sense.

That the corpora dentata have some particular function very different from that which belongs to the rest of the cerebellum, may be inferred from the great difference of their structure, which resembles that of the corpora dentata of the olivary bodies. Their convoluted laminæ consist of small, oval, pyri form, triangular, or otherwise irregular cells, of which each gives off a number of processes continuous with fibres of the white substance; whereas in the grey substance of the cerebellum the cells are many times larger, and different in kind. I am, Sir, respectfully yours,

Belgravia, Sept. 1858. J. LOCKHART CLARKE, F.R.S.

ON

\section{THE ADMINISTRATION OF CHLOROFORM.} To the Editor of THE LANCET.

Str, - - I regret exceedingly having to comment on another death from chloroform which has just occurred at Ewell. I have no doubt every precaution was taken, and that every restorative was had recourse to, after the accident. But I do consider the exhibition of chloroform on a sponge or napkin as most unadvisable after the many fatal cases there have been from that mode of administration. I have seen two letters in The Times this week, both of them suggesting caution and advice; but they do not strike at what $I$ consider the root of the evil-the mode of administration. Chloroform has been in full use in this country for the last eleven years, and during the whole of that period Dr. Snow and myself have made use of an apparatus which bears his name, by which one can be certain of the very large dilution of this most potent vapour with common air, besides being able to moderate the rapidity of its introduction into the system to a nicety, thereby rendering it manageable and comparatively safe. In our joint experience, which I may confidently say is the largest of any two men in England, we have only met with three fatal cases from chloroform with this apparatus; and it will be found that almost all the deaths from chloroform have occurred when it has been given on a sponge or handkerchief. It would be a great misfortune to destroy the public confidence in so great a blessing by the reckless manner of its administration; and I think this is a favourable opportunity for expressing my conviction, based upon long experience in the use of Snow's appa ratus, that this is the safest way of administering chloroform, and that by its more general adoption the casualties would be much diminished.

I am, Sir, your obedient servant,

Brook-street, September, 1858. HENRY POTTER, M.R.C.S.

\section{SMAIL - POX SUPERVENING ON MEASLES SCARLATINA, AND SYPHILITIC SCALY ERUPTION. \\ To the Editor of THE Lancer.}

SIR, - In your number of August 28th I find a highly-interesting article from Dr. Brooke Gallwey, of the Royal Artillery, on a case of variola which supervened on measles, as also of one on scarlatina. He adduces these cases to show that the poison of variola may coexist in the system with that of measles and also with that of scarlatina; and that these facts negative the doctrine of Hunter, that no such poisons can coexist: a doctrine fully subscribed to by Dr. Chambers and the schools since Hunter's time. The cases recorded by Dr. Gallwey go far to question the immutability of this supposed law, and are amply sufficient to ereate enquiry upon a subject so full of professional interest. To these cases I may add one which gives strength to the exception taken to the law; a case of variola supervening on a scaly syphilitic eruption in a young man well poisoned at the time with the syphilitic virus.

Gunner B. S-, Royal Artillery, aged twenty, was ad- mitted to the Orduance Hospital at Limerick on the 20 th of July, 1855, with gonorrhœen, and was discharged, cured, on the lst of August. On the 10 th of the same month he returned with an ulcer on the glans, circular, with elevated edges and hard base. This sore was well burned, and he was cured of it on the 25th. A small chronic bubo remained in his left groin. On the 2 Sth of October he returned to hospital with this bubo, soft and slugrish, but not open, and a scaly eruption (syphilitic psoriasis) over the forehead, shoulders, and body. I opened the bubo, which, with the eruption, proceeded tardily, from the poisonous state of the system, until the 1st December, on which day he had a shivering, followed by feverish symptoms, thirst, dry tongue, hot skin, quick pulse, and pain in the back. On the 4th the skin got quite red; elevated papules appeared on the face, neck, and breast, which daily extended. On the 9th the eruption was well developed in the true characters of distinct variola. The pustule ran through its stages, and the scabs fell on the 20 th.

During the invasion and development of the variolous disease, it was as curions as it was interesting to observe the scaly eruption receding before its more active and formidable rival, like the process of a dissolving view. During the whole time the bubo remained open; and its granulations could not be got to assume a healthy action until the 5th of January, 1856 .

From the 20th of December, when the scabs fell off, to the 8th of January, the skin was gradually improving from the effects of the variola, and the man's strength was increasing; however, on the latter day, a papular eruption, with a few small scaly patches, appeared on the forehead, and on the 12th it was well out on the body and legs. Iritic inflammation also seizer upon the left eye. It was too evident that his old enemy, the syphilitic eruption, had again made its appearance, iu a new form. He made little progress towards recovery till the 16th of February; but from this date he so rapidly progressed that he was discharged from the hospital, a convalescent, on the lst of March, having been four months an inmate under these maladies.

This young man was admitted on the 2Sth of October. On the 10th of November, when the scaly eruption was fully out upon him, a lad was placed in the next bed, in whom severe small-pox developed itself, causing his removal to a detached building; and on the Ist of December, as detailed, Sshowed the first symptoms of the small-pox infection. The lad's exposure appears to have been the origin of the malady in $\mathrm{S}-$ - 's case. Both men bore marls of perfect raccination, $\mathrm{S}$ having the protective cicatrix deep and well defined in each arm.

I fully reported this interesting case at the time to $\mathrm{Dr}$ Maclean, Inspector-General of Hospitals, Dublin, as I conceived it was unique in its character, and entirely subversive of Hunter's doctrine, that no two poisons could co-exist in the same individual at the same time.

The features of the foregoing case are very peculiar. In the first instance, the man had his blood poisoned by a gonorrhoa, subsequent to the cure of which, in ten days, he contracted the chancre. In two months he returns with a bubo and scaly eruption, and in this poisoned state of his srstem, having been exposed to the variolous infection, he is seized with the disease, which dissipates the scaly manifestation of the syphilitic poison. As the small-pox disappears he becomes covered with papular secondary disease; a few scales upon the forehead and characteristic iritis complicate the malady.

It is quite manifest that the venereal poison did not protect the system from the invasion of the variolous, or prevent or modify its development in this case; nor did the poison of the variola extinguish, though it may be said to have modified, the syphilitic poison. They evidently co-existed, the one remaining dormant, whilst the more virulent exhausted the stages of its career, to give place in turn to a member of the family, which originally occupied, but did not abandon the field of its operations.

Looking farther into this case, we might legitimately ask, did the scaly syphilitic disease, which eridently had its origin in the primary chancre, and which occurred so soon after the cure of the gonorrhœa, keep in abeyance its papular poison by virtue of the greater intensity of the former, (adopting $\mathrm{Mr}$. Carmichael's riews of these relationships, until that scaly poison itself became modified by the variolous virus in such manner as to permit the introduction on the stage of the secondary papular poison of the original gonorrhœa?

Curious as is the history of this interesting case, an important fact in medical science is introdnced by it to our notice, having a substantive analogy to principles deducible from the cases so ably laid before the profession by Dr. Gallwey, but pointing 
with a dubions significance to the proposal of M. Justin Lukomaski, of the Finssian service, which would introduce the vaccine virus as a cure for syphilitic disease.

Analogous to the question under consideration is that involved in the mercurial treatment of syphilis. If it be true that mercury cures syphilis, or is administered for that purpose, by establishing a fever or irritation in the system, which has the power of clissipating the venereal irritation, it is but an assumed example of one poison superseding the other; but every man of experience knows that neither the specific nor irritative action of mercury thoronghly eradicates the venereal poison. It may heal a sore, prevent the full development of secondaries, or disperse their manifestations; but that it has not an eradicating power, that its poison does not dissipate from the organizations or the fluids the syphilitic poison, but that they may co-exist and their manifestations be patent together, is equally true. How often have the secondary effects of venereal appeared at a time when the constitution was thoroughly under the influence of mercury-how often men have contracted the disease in the same condition, those can tell whose opportunities have afforded the examples.

In Jannary last, a driver of the Artillery was affected with chancre, for the cure of which he was salivated. While in hospital, and under the inflence of the mercury, a rubeolar rash appeared well out upon the body, of the true type. For the treatment of these he was forty four days in hospital. On the 26th of April he returned with secondary iritis of the right eye, was again put under the influence of mercury, and cured on the 5th of May. On the 22nd of May he canie back with an extensive papular eruption over the face, body, and arms. He was put upon generous diet, sarsaparilla, and iron, and went out cured on the 2 nd of June. In this case it is quite clear that the existing mercurial action did not destroy, in the system, the poison which developed the secondary rash, nor did the second mercurial action for the iritis prevent the subsequent manifestation of the papular disease. Of how many cases is this last the type?

$$
\begin{aligned}
& \begin{array}{l}
\text { I am, Sir, faithfully yours, } \\
\text { Ordnance Hospital, Limerick. }
\end{array} \\
& \text { Sept. 1858. Surgeon to the City of Limerick Infirmary. }
\end{aligned}
$$

\section{To the Editor of The LaxceT.}

SIR,-In the number of THE LA IrCET of the 2Sth ult., there is a notice of the concurrence of small-pox with measles and with scarlatina respectively. I beg leave to record a case of small-pox with measles and purpura hæmorrhagica:-

In the summer or autumn of 1845 , I saw in Rochester two cases of small-pox with measles. One man, residing in one of the lanes of the city, had the concurring affections mildly, and recovered. The other man, residing on the common (which is on a low level), died on the eighth day. He was a sailor, young (about twenty-six years, I believe), and of stout conformation. The variolous pocks appeared during two days; then the rash of measles came out, and increased for four days; then the variolous pocks progressed rapidly, and at this period (sixth day), purpura showed itself. The variolons pocks remained stationary during the progress of the measles, but they were fully maturated at the period of death-viz., the eighth day. There was inflammation of the lungs, attended with much dyspnoea, and there was abundant eruption in the pharynx; the cellular tissue of the body generally, but especially the neck, was swollen. His head also was hot and swollen. Hæmorrhage took place from the bronchial membrane, and from the bladder; and there were spots of purpura over his skin. He died from slow suffocation, due to mal-aëration of the blood. The window of the apartment was kept open (with muslin nailed across it) day and night, with the effect of rendering the air of the room tolerable.

Shortly before the occurrence of the preceding cases, a Jew died at Strood, next Rochester, of scarlatina with purpura hæmorrhagica. He died on the 23rd of July, the seventh day of the disease. I am, Sir, your obedient servant, Chatham, Kent, Sept., 1858. Fred. J. Browy, M.D.

\section{UNWHOLESOME FISH AND POULTRY.} To the Editor of The LAxCET.

SIR,-As there are frequent complaints of the sale of unwholesome fish and poultry in London, I have made some in. quiries into the cause, and send the results for publication in your journal, hoping it may tend to promote the public health.
Fish is sold at Billingsgate by auction by salesmen, most of whom are owners of the vessels, to other silesmen, teehnically called "bummarees," and the fishmongers. The "bummarees" sell them to the retailers or costermongers, and to such fish moncers as require a large quantity. The fishmongers select the best quality, but occasionally sell it when it becomes stale, of which many persons are aware.

The costermonger, who purchases the "pads," complains that they are sometimes "cased"-that is, the good fish are placed on the outside and the rubbish in the middle. The remedy for this imposition is to complain to the clerk of the market on the spot, who will condemn the bad fish and change it for better. But most frequently the baskets of fish are taken away when purchased, without inspection, in order to save time and trouble; and should the costermonger have purchased a "pig in a poke," the most dangerous diseases are likely to be produced, for, having no redress, he is tempted to impose upon the public. Since, however, prevention is the object of sanitary laws, why do not the two inspectors belonging to the market examine all the pads? Why do they not stand on the dumblighters and watch the cargoes while they are taken from the vessels? Why do they not carefully search into all the fish brought to London by railway? Fish of inferior quality is more likely to be brought into the market by railways than by vessels.

Suppose at some watering-place a sufficient quantity is not caught to send to London, it is kept a day or two until more are obtained; the latter are then placed on the top, in baskets weighing from two to four hundredweight, to be sent to town for sale amongst the costermongers. The stale ones, which may be smelt at some distance, are then dried and smoked, and afterwards oiled over to give them a nice appearance.

Should any one urge that two inspectors only cannot perform the duties above mentioned, surely more could be appointed, and it would be much better for the retailer and the public if a stricter supervision were exercised.

Many persons believe that it would be preferable for the fishmonger to buy direct from the salesman, inasmuch as the public would reap the benefit of greater cheapness.

It is well known that much bad poultry is brought into our markets, especially from Ireland. Having been packed up in tea-chests while warm, it comes over sometimes as "green as grass," to be purchased by costermongers, who sell it, when roasted, in low neighbourhoods.

I am, Sir, your obedient servant,

C. J. B. ALDIS, M.D. Medical Officer of Health for St. George's,

Chester-terrace, Chester-square, Sept. 1858.

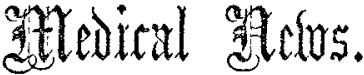

Apothecaries' Harl. - Names of gentlemen who passed their examination in the science and practice of Medicine, and received certificates to practise, on

Thursday, September 2nd, 1858.

DEARDEN, JoHN, Accrington.

MaCkenzie, Monell.

Morris, Geolge Selwyn, Guisborough, Yorkshire. WILKES, EDWIN, Salisbury, Wilts.

(In addition, one gentleman passed his first examination.)

New Medrcal Knignt. - Mr. J. W. Fisher, the Surgeon-in-Chief of the Metropolitan Police, has had conferred upon him the honour of knighthood by her Majesty. Sir J. W. Fisher was surgeon to the old Bow-street police force, and has been superintending-surgeon of the present police since its establishment in 1828 .

Testimoniat to H. T. Woodd, Esq., M.R.C.S.-This gentleman having resigned his situation as assistant union medical officer for the parish of Calstock, with the intention of leaving the neighbourhood, a very general and spontaneous desire was felt by the inhabitants of the parish and others to evince their respect and esteem for him by the presentation to him of a piece of plate. Mr. Allen, the respected relieving officer of the district, was entrusted with carrying out their views and wishes, and he selected a very beautiful silver salver, on which was engraved the following inscription :- "Presented to Henry Turner Woodd, Esq., by the guardians and other officers of the parish of Calstock, in conjunction with the poor and other friends, in testimony of the faithful, zealaus, and 